\title{
How to tell an economic story
}

\author{
Ho Manh Toan \\ Phenikaa University

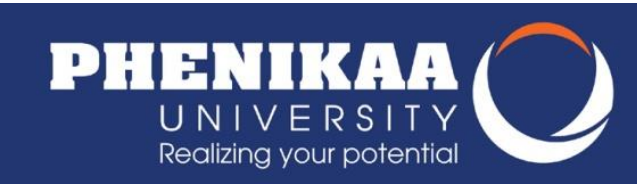 \\ Hanoi, Vietnam \\ January 12,2021
}

Storytelling is fundamentally human. We have passed on our knowledge through a story for generations. In modern times, the story is not only told in traditional means. People have found more innovative ways to effectively engage others in a larger narrative [1-3].

However, for many reasons, only a few communities master the art of storytelling. In contrast, others are struggling to tell their own story, in one way or another. Even though Vietnam escaped poverty and has been rising stably for the last 35 years, its story is opaque even to Vietnamese people. This is due to the fact that Vietnamese people do not learn economics until they enter university [4,5]. Meanwhile, there is a common association between economics and mathematics, making the subject less attractive.

Nonetheless, economics is an attractive field, and it is also fundamentally human. Therefore, one of the greatest contributions of Kinh tế Việt Nam: Thăng trầm và đột phá (2009) is how the book focuses on the fundamentals: a good story, with strong support from statistics, economic foundations, and sensibility [6].

Right from the beginning, the book stated its structure clearly: beginning with the most recent crisis (the global financial crisis in 2007-2008), then rewinding the clock to 1884, and then the Đổi Móri era. The global financial crisis certainly grabs the attention of the reader in 2009. However, the impact still feels the same in 2021 because the 20072008 period was one of the hardest times in recent memory. Then, the authors start their time machine and bring us back to the start, and the journey of how we get to that point: 2008.

Even though the overall structure can seem straightforward with an innovative opening, each chapter of the book focuses on a different component of the Vietnam 
economy, rather than dwelling on retelling events with some analysis. Chapter 8 stresses the bank system, chapter 9 is the asset and the market, chapter 10 presents the stock market, and Part III is dedicated to the problems and future directions. Thus, the reader can freely choose to read in whatever order they see fit. With 554 pages, the authors certainly create unprecedented accessibility to a highly technical subject.

All in all, there are very few books like this on the market [5], and certainly, there will not be many in the future. With one being a respected politician and the other a renowned economist, the authors have provided an unforgettable journey. Kinh tế Việt Nam: Thăng trầm và đột phá (2009) is an instant classic in its own right, and a revisit in 2021 certainly will not waste your time.

\section{References}

[1] Webster, A. (2018). Fortnite has the most interesting video game story in years. Polygon. Retrieved from https://www.theverge.com/2018/7/2/17525200/fortnitestorytelling-rocket-launch

[2] Phillips, M. (2019). The Narrative Experiment That Is the Marvel Cinematic Universe. The New Yorker. Retrieved from https://www.newyorker.com/culture/culturedesk/the-narrative-experiment-that-is-the-marvel-cinematic-universe

[3] Kincaid, C. (2019). Storytelling in Zelda: Breath of the Wild. Japan Powered. Retrieved from https://japanpowered.com/video-games/zelda-botw-storytelling

[4] Ho, M. T. (2021). No Money, No Honey. OSF Preprints. DOI: 10.31219/osf.io/zw6k7.

[5] Ho, M. T. (2021). Books on the Economic History of Vietnam. OSF Preprints. DOI: osf.io/k3pbz.

[6] Chính, P. M., \& Hoàng, V. Q. (2009). Kinh tế Việt Nam: Thăng trầm và đột phá. Nxb Chính trị Quốc gia, Hà Nội. 